\title{
PELATIHAN PEMBUATAN BRIKET DARI ARANG TEMPURUNG KELAPA DI KELURAHAN KOLONGAN SATU KOTA TOMOHON
}

\author{
Meytij J. Rampe \\ Fakultas Matematika dan Ilmu Pengetahuan Alam, UNIMA \\ meytij_rampe@yahoo.co.id
}

\begin{abstract}
Training on the briquettes synthesis from coconut shell charcoal has been conducted. This training was aimed to study the effects starch agent in the from solution on structural growth of briquettes and its chemical properties and the effect of temperature (200-500 oC) on the characters of the briquettes. The product characteristics of briquettes showed that there was a change on the chemical properties of the raw material which has been sintered at $300 \mathrm{oC}$, at which briquettes was produced in this process. Synthesis process at $300 \mathrm{oC}$ in the presence of starch gave carbon material briquettes.
\end{abstract}

Keywords: coconut shell charcoal, synthesis, briquettes.

\section{PENDAHULUAN}

Bagian tanaman kelapa yang belum maksimal penggunaannya adalah tempurung kelapa. Selama ini tempurung kelapa hanya dianggap sebagai limbah industri pengolahan kelapa terutama dari industri minyak kelapa dan hanya dibuang atau dibakar secara langsung. Menurut Mandey (2007) jika tempurung kelapa diolah lebih lanjut akan memberikan manfaat dan nilai ekonomis yang lebih tinggi. Salah satu cara untuk mengolah tempurung kelapa adalah melalui proses pirolisis. Rampe (2010) menyatakan melalui proses pirolisis akan didapatkan arang tempurung kelapa, asap cair, tar, dan gas-gas yang tidak terembunkan. Arang tempurung kelapa dapat diolah lebih lanjut menjadi kokas, yang merupakan bahan bakar padat yang ramah lingkungan.

Arang adalah suatu bahan padat yang berpori dan merupakan hasil pemanasan dari bahan yang mengandung unsur karbon. Sebagian besar dari pori- porinya masih tertutup dengan hidrokarbon, tar dan senyawa organik lain dan komponennya terdiri dari karbon terikat, abu, air, nitrogen dan sulfur. Arang dapat dibuat dengan pemanasan langsung atau tidak langsung dalam timbunan maupun tanur. Pada proses peruraian ini selain arang dapat dihasilkan produk lain berupa destilat dan gas. Produk yang memiliki nilai komersial terutama adalah arang (Rampe, dkk., 2013).

Briket karbon adalah paduan antara unsur karbon dan perekat seperti amilum dan poli vinil alkohol (PVA) serta beberapa bahan perekat tambahan lain. Dalam paduan ini, karbon dan PVA dapat membentuk larutan interstisi di mana material terdistribusi pada ruang kosong di sela-sela antara atom-atom karbon di dalam struktur kristalnya. Briket terbentuk pada komposisi perekat 5 sampai dengan $10 \%$ massa.

Pada pengabdian ini pembuatan briket karbon menggunakan arang hasil 
pirolisis tempurung kelapa, dengan metode pencampuran metode pelarut. Transformasi fasa diakibatkan adanya perubahan kapasitas kalor (C) dan entalpi (H). Pengabdian ini bertujuan untuk melatih proses pembuatan briket dari bahan dasar arang hasil pirolisis tempurung kelapa dan sosialisasi manfaat briket hasil pirolisis tempurung kelapa sebagai bahan bakar yang ramah lingkungan.

Karakteristik matriks briket karbon (karbon-perekat) yang ramah lingkungan baik digunakan pada proses pemanggangan ikan dalam ruangan.

\section{KAJIAN LITERATUR}

Tempurung kelapa mempunyai komponen penyusun yang relatif sama dengan kayu pada umumnya, sehingga tahapan dan hasil pirolisis tempurung kelapa juga sama dengan pirolisis kayu. Komposisi utama tempurung kelapa terdiri dari selulosa, lignin, hemiselulosa dengan kandungan atom-atom $\mathrm{C}, \mathrm{O}, \mathrm{H}$, dan $\mathrm{N}$. Material-material organik ini mengandung gugus fungsional seperti hidroksil (R-OH), alkana (R-(CH2)n-R'), karboksil (R-COOH), karbonil (R-CO-R'), ester (R-CO-O-R'), gugus eter linear dan siklik (R-O-R') dengan variasi jumlah (Rampe, dkk., 2011). Reaksi kimia yang paling umum adalah pembakaran,yang merupakan kombinasi dari bahan bakar dengan oksigen untuk membentuk senyawa produk. Transformasi kimia ini merupakan energi potensial pada skala molekul, dalam hal ini berhubungan dengan posisi atom dan struktur molekul.

Hasil penelitian Tahir, dkk (2009) menyebutkan bahwa tahap-tahap proses pirolisis tempurung kelapa relatif lebih tinggi dari pada kayu. Hal ini disebabkan oleh faktor kekerasan dan kekompakan sel penyusun struktur bahan relatif lebih besar dan lebih rapat dibandingkan dengan kayu secara rata-rata.

Tabel 1. Tahapan Pirolisis Tempurung Kelapa

\begin{tabular}{|l|l|}
\hline Suhu $\left({ }^{\circ} \mathbf{C}\right)$ & Tahapan Pirolisis \\
\hline$<228$ & $\begin{array}{l}\text { Pemanasan tempurung } \\
\text { kelapa }\end{array}$ \\
$228-270$ & $\begin{array}{l}\text { Pengeringan tempurung } \\
\text { kelapa }\end{array}$ \\
$270-338$ & Proses pirolisis tahap I \\
$338-500$ & Proses pirolisis tahap II \\
$>500$ & Pemurnian karbon \\
\hline
\end{tabular}

Tahapan pirolisis tempurung kelapa berdasarkan analisis termal ditampilkan pada Tabel 1. Destilat mulai timbul pada proses pengeringan tempurung, sedangkan gelembung gas timbul pada proses pirolisis tahap I. Tar sebagai produk pirolisis mulai dihasilkan pada proses pirolisis tahap II.

\section{METODE PENGABDIAN}

Alat yang digunakan yaitu: alat pirolisis, alat press, gilingan, ayakan, pisau, ember, oven dan timbangan. Bahan yang digunakan yaitu: tepung kanji dan tempurung kelapa yang berasal dari 
kelurahan Kolongan I, kecamatan Tomohon Tengah, kota Tomohon.

Kegiatan pelatihan yang dilaksanakan di kelurahan Kolongan I kecamatan Tomohon Tengah kota Tomohon ini dilakukan melalui tahap-tahap sebagai berikut :

Tahap I : Persiapan

- Penyampaian informasi rencana pelaksanaan kegiatan sosialisasi dan pelatihan pembuatan Briket dari arang tempurung kelapa sebagai bahan bakar di Kelurahan Kolongan I Kecamatan Tomohon Tengah kepada Lurah Kolongan I dan masyarakat;

- Prasurvey lokasi pelatihan; dan

- Persiapan materi, bahan dan alat yang akan digunakan pada pelaksanaan kegiatan.

Tahap II : Pelaksanaan

Kegiatan pelatihan pembuatan briket dari arang tempurung kelapa di kelurahan Kolongan Satu kecamatan Tomohon Tengah kota Tomohon dilaksanakan pada minggu pertama bulan Mei 2016, berpola pada acuan :

- Peserta kegiatan pelatihan berkumpul di lokasi kegiatan;

- Pengarahan dari kepala lingkungan mewakili Lurah Kolongan I;

- Penerimaan dan perkenalan serta penyampaian maksud dan tujuan kegiatan pelatihan;

- Kegiatan observasi, wawancara, sosialisasi dan pelatihan pembuatan briket dari arang tempurung kelapa di kelurahan Kolongan I kecamatan Tomohon tengah;

- Kegiatan hari kedua peserta pelatihan melatih proses pembuatan briket karbon berbahan dasar arang tempurung kelapa;

- Penjelasan manfaat tempurung kelapa dan material karbon berbahan dasar arang tempurung kelapa;

- Proses pembuatan briket dari bahan dasar arang hasil pirolisis/pemanasan tempurung kelapa; dan

- Material arang tempurung kelapa dapat dijadikan briket dengan nilai kalor tinggi dan merupakan bahan bakar ramah lingkungan.

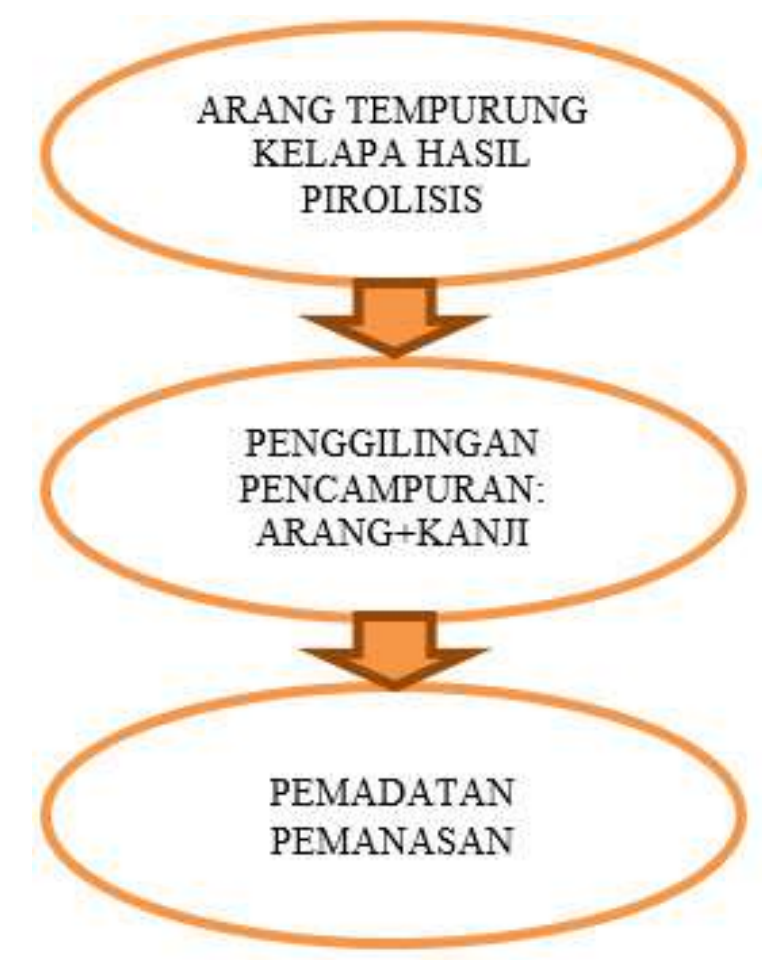

Gambar 1. Diagram alir pembuatan briket 


\section{HASIL DAN PEMBAHASAN}

Kegiatan pelatihan pembuatan briket dari arang tempurung kelapa yang dilaksanakan di Kelurahan Kolongan I Kecamatan Tomohon Tengah, hasil yang diperoleh dideskripsikan sebagai berikut.

\section{Hasil Observasi dan Wawancara}

- Bahan baku tempurung kelapa cukup potensial untuk dijadikan material sumber karbon yaitu briket sebagai bahan bakar.

- Bahan baku tempurung kelapa cukup melimpah di Kelurahan Kolongan Kecamatan Tomohon Tengah.

- Kegiatan pelatihan sebagai sarana untuk pengenalan kepada masyarakat potensi tempurung kelapa sebagai bahan dasar materisl karbon sumber energi yaitu sebagai briket.

- Masyarakat kelurahan Kolongan I kecamatan Tomohon Tengah kota Tomohon dapat memahami pengembangan arang tempurung kelapa sebagai bahan dasar bahan bakar briket.

\section{Hasil Sosialisasi dan Pelatihan}

- Kegiatan pelatihan memberikan masukan kepada masyarakat kelurahan Kolongan I kecamatan Tomohon Tengah tentang manfaat limbah tempurung kelapa.

- Kegiatan pelatihan memberikan ketrampilan bagaimana proses pembuat an material karbon yaitu briket yang potensial dan baik, berbahan baku arang tempurung kelapa sebagai sumber energi.

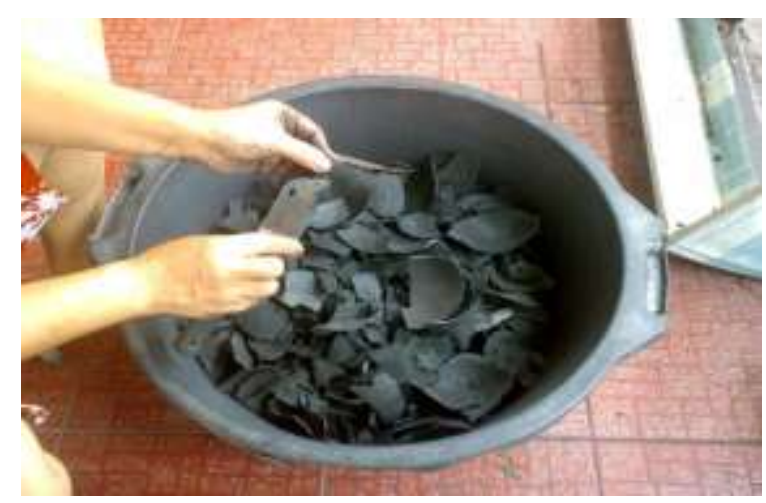

Gambar 2. Arang tempurung kelapa

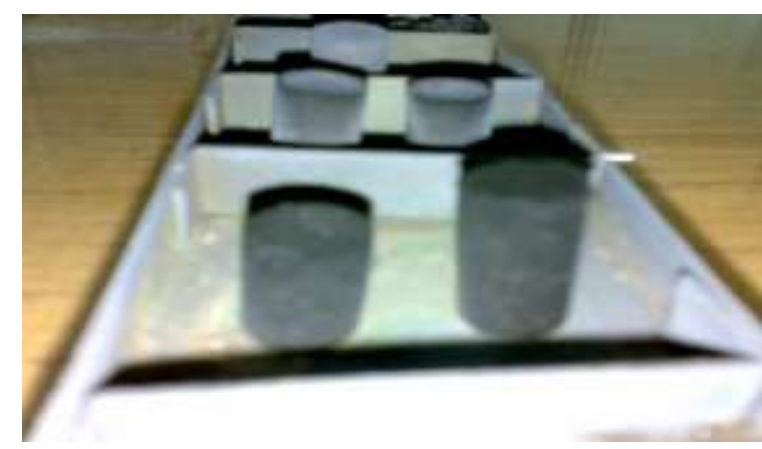

Gambar 3. Briket tempurung kelapa

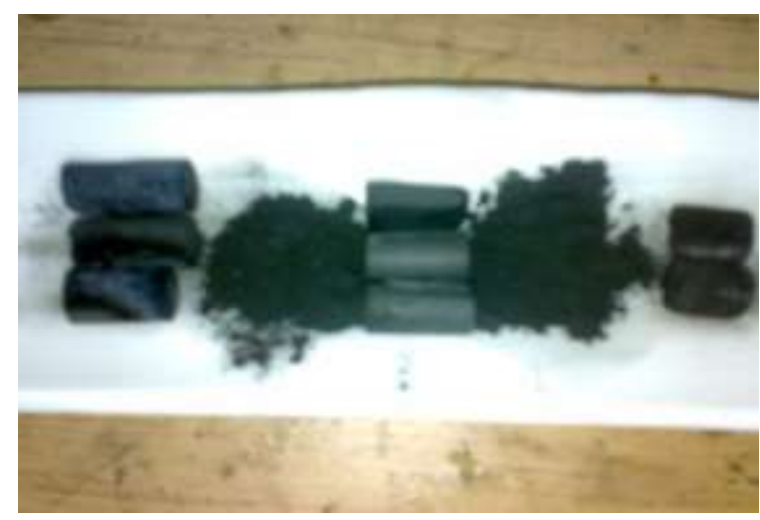

Gambar 4. Serbuk dan briket tempurung kelapa. 


\section{KESIMPULAN}

Bahan baku tempurung kelapa, yang merupakan limbah dari buah kelapa dan baru dim anfaatkan sebagai bahan bakar tradisional, sangat potensial di kelurahan Kolongan Satu, kecamatan Tomohon Tengah, kota Tomohon. Adanya prospek yang baik untuk pengembangan produksi bahan bakar briket berbahan baku arang tempurung kelapa.

\section{KEPUSTAKAAN}

Mandey, L.L., 2007, Biokonversi: Teknologi Pemanfaatan Limbah Industri Pertanian, Sidang Senat Terbuka, Universitas Sam Ratulangi Manado, Manado.
Rampe, M.J., Setiaji, B., Trisunaryanti, W. dan Triyono, 2010, Potensi Biokokas Hasil Pirolisis Tempurung Kelapa Sebagai Bahan Bakar Ramah Lingkungan, Prosiding, Konferensi Nasional Kelapa VII, Manado, 26-27 Mei 2010, 426-435.

Rampe, M.J., Setiaji, B., Trisunaryanti, W. dan Triyono, 2011, Fabrication and Characterization of Carbon Composite from Coconut Shell Carbon, Indo.J.Chem., 11:2, 124-130.

Rampe, M.J., Tiwow, V.A., dan Rampe, H.L, 2013, Potensi Arang Hasil Pirolisis Tempurung Kelapa sebagai Material Karbon, SAINSMAT, 11:2, 191-197.

Tahir, I., 1992, Pengambilan Asap Cair Secara Destilasi Kering Pada Proses Pembuatan Karbon Aktif Dari Tempurung Kelapa, Skripsi, Jurusan Kimia FMIPA UGM, Yogyakarta. 
Jurnal ABDIMAS, Vol. 10, No. 01, Juni 2017 ISSN: 1979-0953 